\title{
Study of frost resistance and drought resistance of apple tree varieties of VNIISPK breeding on clonal rootstock 54-118
}

\author{
Anna Galasheva*, and Nina Krasova \\ Russian Research Institute for Fruit Crop Breeding (VNIISPC), 302030 Gilina, Orel, Orel region, \\ Russian Federation
}

\begin{abstract}
Apple tree varieties on clonal rootstock 54-118 were studied in terms of frost resistance and drought resistance. The purpose of the research is to study the resistance to frost and drought of apple tree varieties of VNIISPK breeding on clonal rootstock 54-118. Climatic conditions affect fruit trees and further lead to a sharp decrease in the fruit productivity and commercial qualities. The problem study of resistance to various extreme growing conditions (including frost, low temperatures, drought and high temperatures) is relevant. A variety that has a high resistance under various adverse weather conditions is considered as winter-hardy, i.e. shows all the components of frost resistance. The study of the main components of winter hardiness (I, III, IV) showed that apple tree varieties (Orlik, Venyaminovskoye, Sinap Orlovsky, Veteran, Svezhest, Rozhdestvenskoye, Bolotovskoye - of the FSBSI VNIISPK breeding; Antonovka obyknovennaya - of local selection on clonal rootstock 54-118) had minor bud damage. The bark and wood were not damaged. When studying the total water content of leaf tissues during the growing season, all varieties on the clonal rootstock 54-118 were assigned to the average level of hydration. In laboratory conditions, over the years of research, the varieties had a high indicator of the ability to restore water content of leaf tissues after drought. On the clonal rootstock 54-118 the apple tree varieties are able to withstand thaws, spring frosts, droughts and dry winds.
\end{abstract}

\section{Introduction}

At the end of the XX and at the beginning of the XXI centuries, Russian and foreign scientists-breeders bred dozens of new, fast-growing and adaptive apple tree varieties suitable for intensive type gardens [1]. Mikhail Iosifovich Sukhotsky, a well-known Belarusian horticulturist and agronomist, wrote: "New varieties are the "locomotive" that puts production on the path of greening and intensification, contributes to the creation of adaptive and highly productive gardens" [2].

Abiotic environmental factors (thaws, spring frosts, droughts, dry winds, etc.) cause great damage to fruit trees and huge damage to agriculture. Any climatic stress affect fruit

* Corresponding author: galasheva@vniispk.ru 
trees and further lead to a sharp decrease in the fruit productivity and commercial qualities $[3,4]$. The purpose of our research is to study the frost resistance and drought resistance of apple tree varieties on clonal rootstock 54-118.

Frost resistance is a hereditary trait of the genotype to resist a complex of unfavorable winter conditions, so the choice of the most resistant winter maturation varieties period is of great importance in production $[5,6]$. The variety, the rootstock, the growing conditions, the age of the tree, the crop load in the previous year - all of this affect the tree frost resistance $[7,8]$.

On the territory of the Orel region, a moderate continental climate prevails, which is accompanied by frosts (early autumn frosts, frosts in the middle of winter, frosts after thaws), aridization, spring burns, frosts during flowering, etc. [9].

In the European part of Russia, dry conditions are often observed in the spring-summer and summer periods. Currently, high temperatures during the summer growing season, frequent droughts have a negative impact on the vital activity of fruit crops. $20-55 \%$ are dry winds and droughts for many years in the Orel region. The processes of photosynthesis and respiration involve water, which affects growth processes, direction of enzymatic and hormonal action, etc. [10]. In case of drought, the ovaries and fruits fall off, the leaves turn yellow, and the growth of annual shoots stops $[11,12,13]$. The water content of leaf tissues and the restoration of water content are physiological indicators that can evaluate the resistance of fruit trees to water deficiency [14]. The analysis of a number of Russian and foreign researchers shows that the rootstock is of great importance in plant resistance to drought. The drought resistance of rootstocks depends on the physiological properties of top and on the root system. The drought resistance properties of rootstocks are also transmitted to a certain extent to the varieties grafted on them $[10,15,16]$. The plant water regime is the main physiological indicator of the ability to restore the water content of leaf tissues after drought [17].

The study of frost resistance and drought resistance of Veteran, Bolotovskoye, Antonovka obyknovennaya, Sinap Orlovsky, Orlik, Svezhest, Venyaminovskoye, Rozhdestvenskoye on clonal rootstock 54-118 is relevant.

\section{Materials and methods}

The research was conducted at the FSBRI VNIISPK, 2016-2018. The objects of research are apple tree varieties: Antonovka obyknovennaya - a control variety of local selection and Venyaminovskoe, Sinap Orlovsky (Fig. 1), Veteran, Orlik, Rozhdestvenskoye, Svezhest, Bolotovskoye of VNIISPK breeding on vegetatively propagated clone rootstock 54-118.

54-118 (PB x 13-14) - semi-dwarf rootstock. It is characterized by high frost resistance of the root system (roots are preserved at $-15^{\circ},-16^{\circ} \mathrm{C}$ ). Rootstock $54-118$ is drought-resistant, slightly affected by pests and diseases, it is used to produce medium-sized trees that begin to bear fruit on 4th-5th year. The wood of the rootstock is strong, the root system is well branched, the trees are well fixed in the soil and do not bend under the load of the crop. Biological feature of the rootstock: little shoot is formed in the garden. It is well compatible with varieties of the middle zone of gardening. Semi-dwarf rootstock 54-118 has been zoned since 1984 in 22 regions and is recommended for extensive production testing [15, $18]$.

The apple tree varieties proposed for planting have good compatibility with the rootstock 54-118, provide good tree development and weak crown.

Planting scheme $-6 \times 3 \mathrm{~m}$. The garden was planted in the fall 2013. Annual apple tree branches were harvested when the average daily air temperature is below $0^{\circ} \mathrm{C}$, simultaneously for all tests, wrapped with a damp cloth and set at a temperature of $-3^{\circ},-5^{\circ} \mathrm{C}$ in bags. Annual branches were frozen in the "Espec" PSL-2KPH chamber after pre- 
hardening at $-5^{\circ} \mathrm{C}$ and $-10^{\circ} \mathrm{C}$ for 5 days. In the climatic chamber of the Japanese brand "Espec" PSL-2KPH, the damaging factors of the winter period were simulated:

I component - resistance of plants to early frosts $-25^{\circ} \mathrm{C}$ without hardening and after hardening in autumn (late November) and in December; III component - plants have the ability to maintain resistance to frosts up to $-25^{\circ} \mathrm{C}$ in February with thaws; IV component plants restore frost resistance up to $-35^{\circ} \mathrm{C}$ during re-hardening after thaw (March). Annual branches were frozen for 8 hours, and the temperature was reduced at a rate of $-5^{\circ} \mathrm{C} /$ hour [19].

After the chamber, the annual branches of the apple tree were placed in containers with water for growing. The assessment of damage to branch tissue was determined by the longitudinal and transverse section (according to browning degree) on a 5-point scale: 0 no damage, 5 - the tissue died.

The study of the indicator of the ability to restore tissue water content after saturation with water of leaves of apple varieties was carried out according to the methodological recommendations of V.G. Leonchenko, 2007 [20]. For the experiment on determination of dry weight and total water content, 5 leaves were taken in two repetitions. The leaves were placed in aluminum buckets and dried at a temperature of $105^{\circ} \mathrm{C}$ in a climate chamber to a constant weight. The variety dehydration was studied (in 2-fold repetition of 5 leaves in each, with the same conditions for all samples). The leaves were selected (evenly from all sides of the tree crown 4-5 leaves from the top of the shoot in three variants in 2 repetitions) in dry sunny weather, in the morning, and placed in bags. Water loss by apple tree leaves was determined at the time (after 4 hours) of dehydration process completion. After four hours of leaves dehydration, they were weighed and placed for 12 hours to be saturated with water, so the indicator of the ability to restore the water content of apple tree leaves tissues was determined.

Statistical data processing was performed by the method of variance analysis [21].
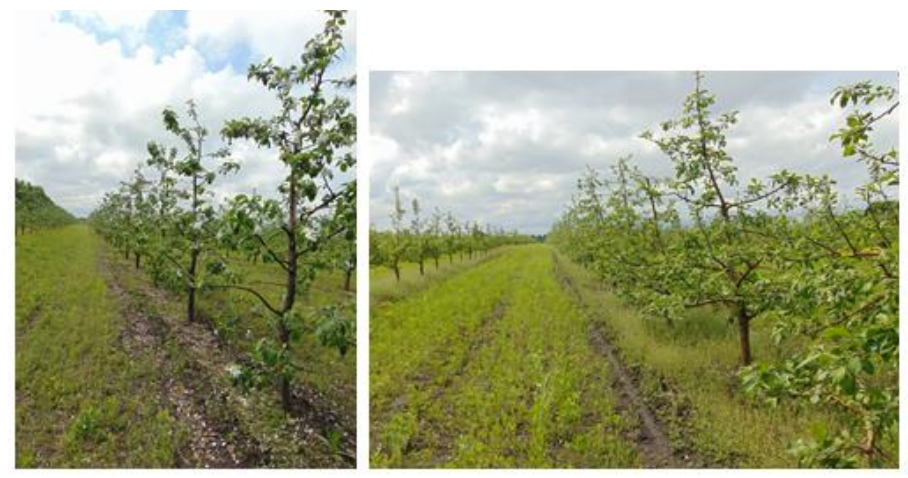

Fig. 1. Apple tree varieties Sinap Orlovsky (left) and Venyaminovskoye (right) on the clonal rootstock 54-118

\section{Results and discussion}

The analysis of studies showed that during the freezing of annual branches without hardening, the apple tree varieties Orlik, Venyaminovskoe and Veteran had bud damage at the level of Antonovka obyknovennaya - control. At the beginning of winter, without hardening at a temperature of $-25^{\circ} \mathrm{C}$, the freezing of buds in the varieties Rozhdestvenskoye (1.2 points), Bolotovskoye (1.2 points), Svezhest (1.9 points) and Sinap Orlovsky (1.2) is significantly higher than in the control - Antonovka obyknovennaya (0.7) (Fig. 2). 
After hardening and gradual decrease in temperature to $-25^{\circ} \mathrm{C}\left(5\right.$ days at $-5^{\circ} \mathrm{C}$ and 5 days at $-10^{\circ} \mathrm{C}$ ) frost resistance of the buds during hardening increased in Antonovka obyknovennaya, Veteran, Orlik, Venyaminovskoe, Rozhdestvenskoe, Svezhest, Sinap Orlovsky, Bolotovskoe. Bud damage in the varieties Venyaminovskoye, Bolotovskoye, Sinap Orlovsky and Rozhdestvenskoye was at the level of Antonovka obyknovennaya control (Fig. 2).

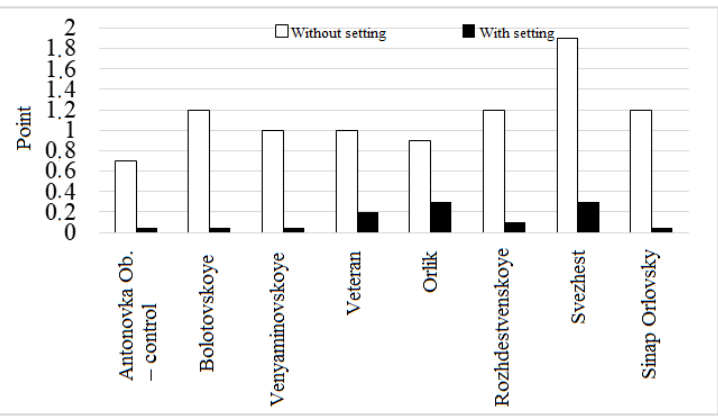

Fig. 2. The degree of bud freezing in autumn (late November) and early winter (December) at a temperature of $-25^{\circ} \mathrm{C}$ without hardening (LSD0.05 $=0.4$ ) and after hardening (LSD0.05=0.2), (20162017)

Determination of frost resistance up to $-25^{\circ} \mathrm{C}$ after thaws (III component) is of great importance. Due to changes in climatic conditions, the number of warm winters has increased in recent decades, which negatively affects the frost resistance of apple trees [22]. At the III component (after thaws), a high ability to maintain frost resistance was noted in the varieties Venyaminovskoe, Sinap Orlovsky, at the level of Antonovka obyknovennaya. Bud freezing was found in Bolotovskoe variety - 1.0 point and Svezhest variety - 1.8 points. The degree of bark freezing in the Svezhest variety is 0.5 points. The remaining varieties had a degree of bark freezing at the level of Antonovka obyknovennaya - control. The wood of the varieties turned out to be frost-resistant. In February, after a three-day thaw, $+5^{\circ} \mathrm{C}$ and temperature decrease up to $-25^{\circ} \mathrm{C}$ in all varieties of VNIISPK breeding, bud damage is significantly higher than in the Antonovka obyknovennaya variety - control. The maximum score of bud damage was noted in Bolotovskoe variety -2.1 points, Svezhest variety -2.4 points. The degree of bark freezing is from 0.3 points in the Venyaminovskoe variety to 1.3 points in Svezhest variety. The wood was not damaged (Fig. 3).

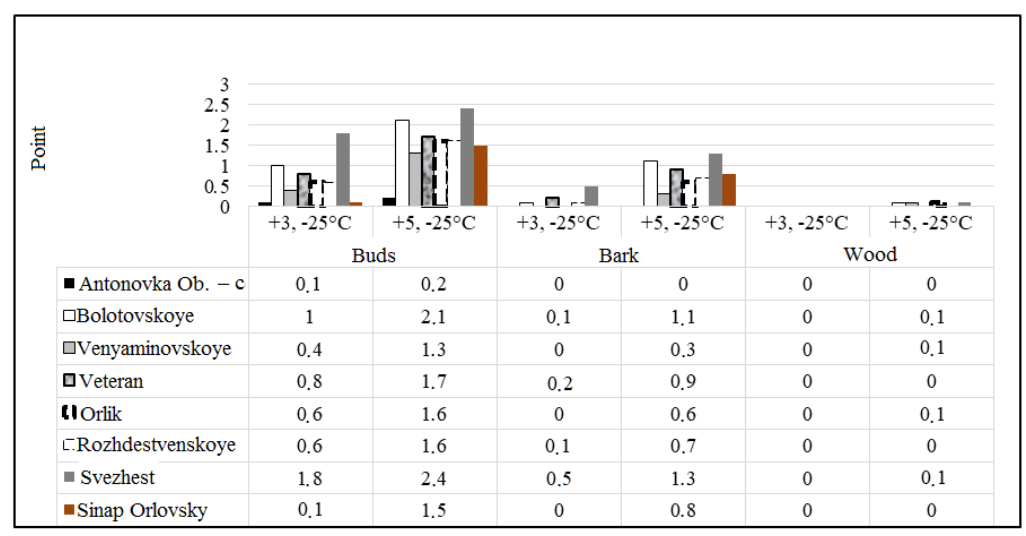

Fig. 3. The degree of freezing of annual branch tissues of apple tree varieties under the conditions of the III component of frost resistance (LSD05 $=$ buds $+3^{\circ},-25^{\circ} \mathrm{C}-0.3$; buds $+5^{\circ},-25^{\circ} \mathrm{C}-0.4$; bark $+3^{\circ},-25^{\circ} \mathrm{C}-0.2$; bark $+5^{\circ},-25^{\circ}-0.5$; wood $+3^{\circ},-25^{\circ} \mathrm{C}-\mathrm{Ff}<\mathrm{Ft}$; wood $+5^{\circ},-25^{\circ} \mathrm{C}-\mathrm{Ff}<\mathrm{Ft}$ ) 
At the IV component of annual branch freezing, it was shown that at the level of Antonovka obyknovennaya (control), all the studied varieties had a good ability to restore frost resistance. Bud freezing in the Svezhest variety was marked by 0.4 points, compared with the control variety Antonovka obyknovennaya - 0 points. The wood and bark were without damage.

Low temperature $\left(-30^{\circ} \mathrm{C}\right)$ with hardening after thaw $\left(+5^{\circ} \mathrm{C}\right)$ did not affect bark and wood frost resistance of apple tree varieties. Bud freezing was insignificant in the Veteran variety -0.8 points, Bolotovskoe variety -0.8 points and Svezhest variety -1.1 points (Fig. 4).

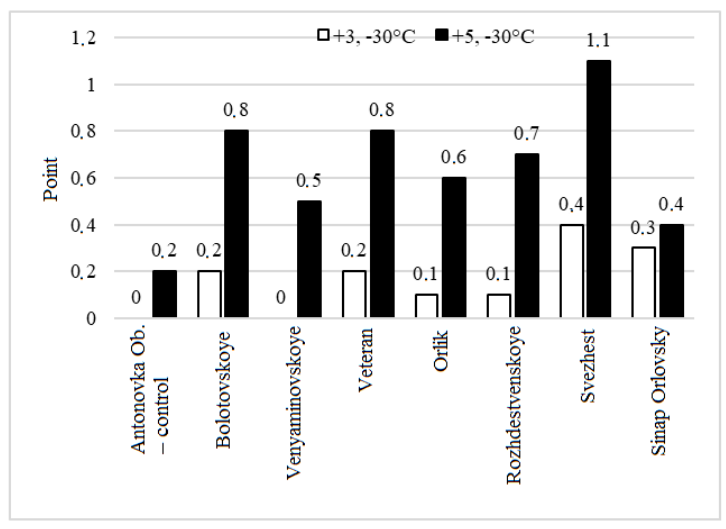

Fig. 4. The degree of bud freezing of apple tree varieties (IV component) at frost $-30^{\circ} \mathrm{C}$ after threeday thaws +3 and $+5^{\circ} \mathrm{C}\left(\mathrm{LSD} 05=\right.$ buds $+3^{\circ},-25^{\circ} \mathrm{C}-0.3$; buds $\left.+5^{\circ},-25^{\circ} \mathrm{C}-\mathrm{Ff}<\mathrm{Ft}\right)$

During the growing season of plants, precipitation plays an important role, primarily affecting the growth, development, setting and differentiation of generative buds, flowering, fruit setting and ripening. The indicator of the ability to restore leaf water content after drought is one of the important parameters of the plant water regime.

In the Orel region, there is little precipitation in the summer, and there is a long drought period. The analysis of the studies showed that the growing season 2017 is characterized by optimal conditions of humidification according to the hydrothermal coefficient (HTC in the range of 1.0-1.4). In June 2017, precipitation fell - $59.6 \mathrm{~mm}$, HTC 1.3, maximum air temperature is $+29^{\circ} \mathrm{C}$. In June, the average water content level of young leaves was detected from $62.5 \%$ of Synap Orlovsky to $67.9 \%$ of Antonovka obyknovennaya.

In July 2017 , at a maximum air temperature of $+31.6^{\circ} \mathrm{C}$, precipitation amount of 75.0 mm, HTC 1.3, the water content of leaf tissues decreased in the studied varieties: Rozhdestvenskoe - 65.8\%, Bolotovskoe - 57.3\%, Veteran - $64.3 \%$. The varieties Antonovka obyknovennaya $-70.2 \%$ and Sinap Orlovsky $-71.6 \%$ had a high indicator of leaf tissue water content. In August, the precipitation amount was $100.8 \mathrm{~mm}$, the HTC 1.7 , the maximum air temperature $+32.0^{\circ} \mathrm{C}$, but during this period, there was a decrease in leaf tissues water content in all varieties, since during this period the fruit is forming and maturing.

Weather conditions in 2018 turned out to be more arid (insufficient moisture is considered when the HTC is less than - 1.0), especially in June (HTC - 0.4) and August (0.2). Tissue water content in June and July was characterized by an average level. July was wet $-77.9 \mathrm{~mm}$ of precipitation, HTC - 2, the maximum air temperature reached up to $29.3^{\circ} \mathrm{C}$, while an increase in leaf tissue water content in Orlik variety was noted $-2.3 \%$, in Svezhest - $7.5 \%$. The leaf tissue water content in June and July in the varieties Sinap Orlovsky, Rozhdestvenskoe was on the same level as Antonovka obyknovennaya - control.

The fruit formation and maturation takes place in August, there is a process of water outflow from leaf tissues into fruit. In August 2018, the indicators of leaf tissue water 
content in the varieties decreased compared to July. In the Veteran variety, the water content indicator decreased to $53.1 \%$ in August (Fig. 5). The total water content of leaf tissues of apple tree varieties was determined in the conditions of the North Caucasus. The researchers also noted a significant decrease in leaf water content in August [23].

The different reaction in the experimental apple tree varieties can be explained by the effect of the scion on the development of rootstock root system, which affects the leaf water content in the summer $[10,15,16]$.

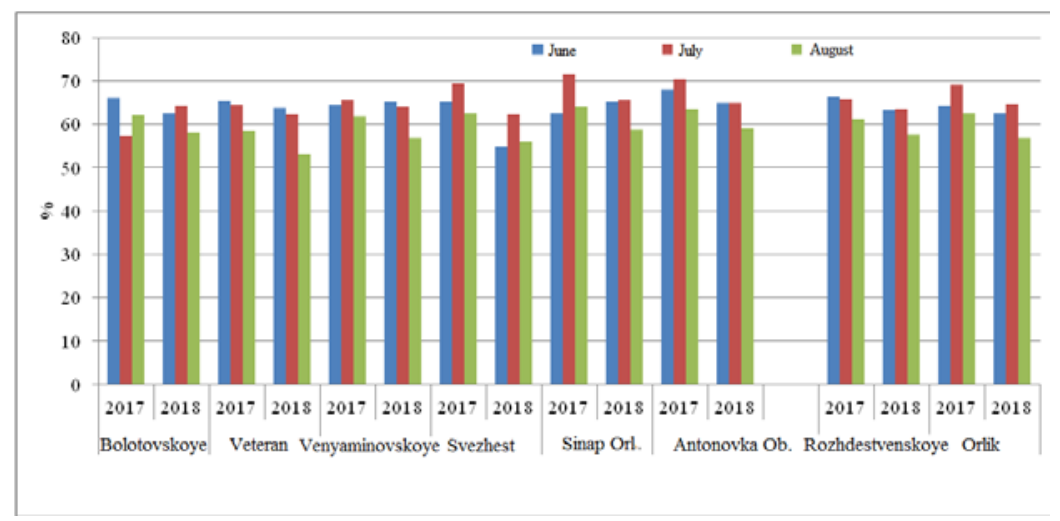

Fig. 5. The indicator of leaf tissue water content of apple tree varieties on the clonal rootstock 54-118 in the growing season (2017-2018), \%

In June 2017, in laboratory conditions, the indicator of the ability to restore leaf tissue water content was high, from $108.0 \%$ in the Venyaminovskoe variety to $177.2 \%$ in the Rozhdestvenskoe variety. In July, the Venyaminovskoe variety showed an increase in the ability to restore the leaf tissue water content by $11.9 \%$. In the remaining varieties, the ability to restore water content of apple tree leaf tissues decreased: from $22.8 \%$ in the Antonovka obyknovennaya variety to $49.4 \%$ in the Bolotovskoe variety, while the indicator of the ability to restore leaf tissue water content in the studied varieties is high. In August, the leaf tissue water content increased in the varieties Bolotovskoe, Orlik, Antonovka obyknovennaya, Sinap Orlovsky - 15.9-16.9\%, while in the other varieties the indicator decreased (Fig. 5).

In 2018, in June, after drought and water saturation of leaves in the laboratory, a high indicator of the ability to restore leaf tissue water content was revealed in all the studied varieties from $109.9 \%$ in Antonovka obyknovennaya to $190.5 \%$ in Rozhdestvenskoe. In July and August 2018, the average indicator of the ability to restore apple tree leaf tissue water content was found in the following varieties: Veteran (August - 60.5\%), Rozhdestvenskoe (July $-67.8 \%$, August $-67.4 \%$ ). In these months, the rest of the varieties had a high indicator of leaf tissue water content restoration (July - 80.7-100.1\%; August 72.6-115.8\%) (Fig. 6). The ability to restore water content of fruit crops leaves after the drought was also studied by other authors [24, 25]. 


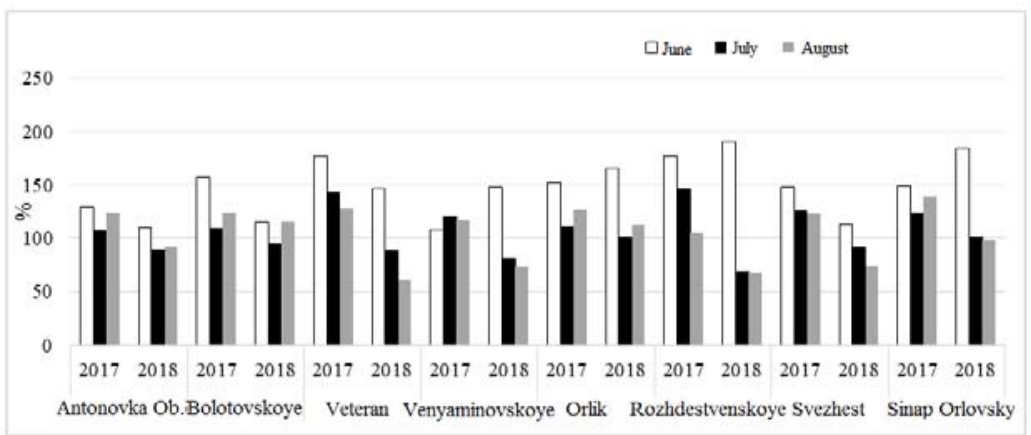

Fig. 6. - The indicator of the ability to restore water content of apple tree lear tissues after saturation with water in the laboratory, $\left(\operatorname{LSD}_{0,05}=\mathrm{F}_{\mathrm{F}}<\mathrm{Ft}\right.$ )

\section{Conclusions}

Semi-dwarf rootstock 54-118 (PB x 13-14) is characterized by high frost resistance of the root system (roots are preserved at $-15^{\circ},-16^{\circ} \mathrm{C}$ ), drought-resistant, its trees begin fruiting on 4-5 years after planting, produce high yields. Varieties on clonal rootstock 54-118 are widely used in industrial gardens of the Central Chernozem region of Russia.

Studies of apple tree varieties on clonal rootstock 54-118 on the main components of winter hardiness (I, III, IV) showed the following: 1. Hardening affected the increase in the resistance of apple buds to frost in December (I component);

2. Freezing of annual branches at III component $\left(+3^{\circ} \mathrm{C}\right.$ and $\left.+5^{\circ} \mathrm{C}-25^{\circ} \mathrm{C}\right)$ showed that most apple tree varieties had a slight bud freezing;

3. With the IV component of winter hardiness, it turned out that all varieties on the clonal rootstock had the ability to quickly restore frost resistance during thaws $+3^{\circ}$ and $+5^{\circ} \mathrm{C}$ at a return frost of $-30^{\circ} \mathrm{C}$ in late winter and early spring (March).

All the studied varieties on the clonal rootstock 54-118 had reversible bud damage.

When studying the total water content of leaf tissues during the growing season, all varieties on the clonal rootstock 54-118 were assigned to the average level of hydration. The varieties had a high ability to restore water content of apple tree leaf tissues in the laboratory after the drought during the study period.

Apple tree varieties of the FSBSI VNIISPK breeding on clonal rootstock 54-118 are able to withstand thaws, spring frosts, droughts and dry winds.

\section{References}

1. A.N. Yushkov, Dissertation for the degree of Doctor of Agricultural Sciences, 377 (2017)

2. M.I. Sukhotsky, The book of the modern gardener, 528 (2009)

3. N.G. Krasova, Z.E. Ozherelyeva, L.V. Golishkina, M.A. Makarkina, A.M. Galasheva, Winter hardiness of apple cultivars, 184 (2014)

4. N.G. Krasova, A.M. Galasheva, L.V. Golishkina, Proceedings of the Latvian Academy of Sciences, Section B: Natural, Exact, and Applied Sciences, 67(2), 136 (2013)

5. N.N. Savelyeva, N.I. Savelyev, State and prospects of Northern horticulture development, 107 (2016)

6. M.M. Tyurina, N.G. Krasova, S.V. Rezvyakova, N.I. Saveliev, E.N. Dzhigadlo, T.P. Ogoltsova, Program and methods of fruit, berry and nut crop breeding, 59 (1999) 
7. E.N. Sedov, N.G. Krasova, Low-growth rootstocks as inserts and new apple tree varieties of the VNIISPK for intensive type gardens, 80 (2000)

8. N.G. Krasova, A.M. Galasheva, Z.E. Ozherelyeva, L.V. Golishkina, M.A. Makarkina, Agricultural biology, 49(1), 42 (2014)

9. N.G. Krasova, Z.E. Ozherelyeva, A.M. Galasheva, O.V. Panfilova, M.F. Zoyi, E3s Web of Conferences, 176, 03017 (2020) https://www.researchgate.net

10. E.A. Goncharova, Water status of cultivated plants and its diagnostics, 112 (2005)

11. T.V. Chirkova, Physiological bases of plant drought resistance, 240 (2002)

12. A.M. Galasheva, N.G. Krasova, Z.E. Ozherelyeva, A.R. Pavel, Fruit and berry growing in Russia, 47, 82 (2016)

13. A.V. Solonkin, A.V. Semenyutina, O.A. Nikolskaya, E.N. Kikteva, Bulletin of the Nizhnevolzhsky Agrarian university complex: science and higher professional education, 4, 56 (2019)

14. J. Farrant, M. Jenks, A. Wood, In Plant Desiccation Tolerance, 51 (2002)

15. V.A. Gryazev, Growing seedlings for highly productive gardens, 208 (1998)

16. K. Klamkowski, W. Treder, Fruit and Ornamental Plant Research, 10, 31 (2002)

17. Z.E. Ozherelieva, N.G. Krasova, A.M. Galasheva, Nauchnoe obozrenie, 1, 10 (2013)

18. V.A. Potapov, V.M. Lebedev, N.N. Gusev, Winter-hardy low-growing clonal apple tree rootstocks, 275 (1990)

19. M.M. Tyurina, G.A. Gogoleva, N.V. Efimova, L.K. Goloulina, N.G. Morozova, I.I. Echedi, F.A. Volkov, A.P. Arsentiev, N.A. Matyash, Methodical instructions (2002)

20. V.G. Leonchenko, R.P. Evseeva, E.V. Zhbanova, T.A. Cherenkova, Laboratory assessment of flowers and buds of apple trees resistance to spring frosts, In methodical recommendations Pre-selection of prospective genotypes of fruit plants for ecological resistance and biochemical value of fruits, 21 (2007)

21. B.A. Dospehov, Methods of the Field Experiment (1985)

22. Z.E. Ozherelieva, N.G. Krasova, A.M. Galasheva, Contemporary horticulture, 4, 33 (2019)

23. N.I. Nenko, G.K. Kiseleva, E.V. Ulyanovskaya, E.K. Yablonskaya, A.V. Karavaeva, Agricultural Biology, 54(1) (2019)

24. P.S. Prudnikov, Z.E. Ozherelieva, Physiological and biochemical methods for diagnosing the resistance of fruit crops to drought and hyperthermia, 46 (2019)

25. N.I. Saveliev, A.N. Yushkov, N.N. Savelieva, A.S. Zemisov, V.V. Chivilev, R.E. Kirillov, M.Yu. Akimov, M.B. Gladyshev, Al.B. Kruzhkov, A.A. Konyukhova et al, Genetic potential of fruit crops resistance to abiotic stressors, 212 (2010) 